\title{
Surgical management of native valve endocarditis
}

\author{
TAPAS RAYCHAUDHURY. ALAN FAICHNEY, EWJ CAMERON, PR WALBAUM \\ From the Regional Cardiothoracic Centre, Royal Infirmary, Edinburgh
}

\begin{abstract}
From 1972 to 198140 patients have required urgent valve replacement for left-sided bacterial endocarditis. The aortic valve was replaced in 31 patients, the mitral valve in four, and both in five patients. Twenty-six patients $(65.5 \%)$ were in functional class IV heart failure according to the New York Heart Association criteria, and 13 patients (32.5\%) were in class III heart failure at the time of operation. One patient in class II was operated on urgently for multiple cerebral embolism but died of fatal cerebral haemorrhage. In 22 patients (55\%) there were no pre-existing valvular lesions and these patients were found to be more liable to develop severe haemodynamic failure. Premature closure of the mitral valve, documented by M-mode echocardiography, was a useful diagnostic aid and successfully determined the best timing of surgery in 14 out of 20 patients with severe aortic regurgitation. Cardiac arrest before operation appeared to be a significant risk factor $(p=0.0015)$ unless followed by immediate cardiopulmonary bypass. There were eight operative deaths $(20 \%)$. Of 26 patients who were in functional class IV heart failure, 19 were operated on within four days of their haemodynamic deterioration and all survived. The operation was delayed in the remaining seven patients and none of them survived $(\mathrm{p}=0.000003)$. There were no operative deaths among the patients in class III heart failure. There was only one episode of reinfection in the 16 patients followed up for at least three years. The duration of postoperative antibiotic treatment (four to six weeks in our patients), rather than any preoperative antibiotic regimen, seems to be important for preventing reinfection. At present there are 28 survivors, of whom 24 are in functional class I and four in class II.
\end{abstract}

Valve replacement for native valve endocarditis is a well-established treatment, particularly for the patient with intractable heart failure. The initial uncertainty about insertion of a prosthesis in the presence of active infection has disappeared and several reports in recent years have argued strongly in favour of urgent valve replacement irrespective of the stage and control of infection. ${ }^{1-10}$ We describe here our experience of native valve replacement in patients with left-sided bacterial endocarditis after urgent admission to hospital.

\section{Patients and methods}

The names of all patients who required native valve replacement because of bacterial endocarditis from 1972 to 1981 were drawn from the central computer service of our hospital and the Scottish Home and Health Department. The case notes of all patients were then consulted. The latest follow-up data were

Address for reprint requests: Mr T Raychaudhury, Department of Cardiac Surgery, Royal Infirmary, Edinburgh EH3 9YW. obtained from outpatient visits and letters from and telephone conversations with the general practitioners and from questionnaires sent directly to the patients.

The presence of endocarditis was confirmed when at least two of the following criteria were fulfilled: (a) two positive preoperative blood cultures in the presence of relevant clinical features of endocarditis; $(b)$ the presence of vegetations, perforations, or destruction of valve leaflets observed at operation; (c) histological and bacteriological evidence of recent endocarditis on excised valves. The term

Table 1 Indications for surgery

\begin{tabular}{|c|c|c|}
\hline & This series & $\begin{array}{l}1976 \text { world } \\
\text { review }\end{array}$ \\
\hline & No (\%) & No (\%) \\
\hline $\begin{array}{l}\text { Haemodynamic failure } \\
\text { Persistent infection } \\
\text { (drug intolerance) } \\
\text { Embolism }\end{array}$ & $\begin{array}{r}32(80) \\
4(10) \\
{[1]} \\
4(10)\end{array}$ & $\begin{array}{l}190(77) \\
31(12 \cdot 6) \\
[4]]_{5}(10)\end{array}$ \\
\hline Total & 40 & 246 \\
\hline
\end{tabular}


Table 2 Distribution of patients with heart failure according to predisposing factors

\begin{tabular}{llllll}
\hline Predisposing factors & $\begin{array}{l}\text { No (\%) } \\
\text { of patients }\end{array}$ & $\begin{array}{l}\text { No of patients in } \\
\text { NYHA class III } \dagger\end{array}$ & $\begin{array}{l}\text { No of patients in } \\
\text { NYHA class IV } \dagger\end{array}$ & $\begin{array}{l}\text { No of patients } \\
\text { requiring urgent } \\
\text { operation }\end{array}$ & $\begin{array}{l}\text { No (\%) of } \\
\text { deaths }\end{array}$ \\
\hline $\begin{array}{l}\text { Normal } \\
\begin{array}{l}\text { Congenital } \\
\text { (bicuspid) }\end{array}\end{array}$ & $22(55)$ & 4 & 17 & 14 & $5(22 \cdot 7)$ \\
Rheumatic & $10(25)$ & 5 & 5 & 3 & $2(20)$ \\
\hline
\end{tabular}

*One patient with a normal valve was in class II.

†Functional classification of New York Heart Association. ${ }^{11}$

active infection is used when the blood culture was positive within the 24 hours before operation and organisms were seen on the excised specimens at the microscopic examination or a positive culture was obtained from the valves or adjacent tissue. The term normal valve is used when there was no history of a pre-existing valvular lesion, when an anatomically normal valve was excised, and when there was no histological evidence of a previous pathological condition. The term haemodynamic deterioration is used when a patient was deteriorating from functional class I or II to class III or IV heart failure; the severity of heart failure was assessed according to the New York Heart Association (NYHA) functional classification. ${ }^{11}$ Operative death is defined as death occurring within 30 days of operation. The statistical data were analysed with Fisher's exact test and the $\chi^{2}$ test, with Yates' correction for continuity.

There were 34 male and six female patients. The average age of the men undergoing surgery was 48 years (range 18-71 years) and for female patients 43 years (range 20-65 years). In all but one patient either a new murmur or a change in the existing murmur was audible. Twenty-six patients $(65.5 \%)$ were in NYHA functional class IV and 13 patients $(32.5 \%)$ were in class III. One patient was in class II heart failure but was operated on urgently for lifethreatening multiple cerebral embolism.
Thirty-two out of 40 patients $(80 \%)$ were operated on for haemodynamic failure, four for persistent infection, and the other four for multiple embolic episodes (table 1). In 19 out of 26 patients who were in NYHA class IV the operation was performed within 3-72 hours of haemodynamic deterioration. In the remaining seven patients the operation was delayed for more than four days and up to 11 days. Most patients in class III showed relatively slow but progressive deterioration and operation was performed often because of persistent infection or embolism. Twenty patients were operated on for severe aortic regurgitation. Thirteen of these presented with the acute aortic incompe-

Table 3 Bacteria infecting valves

\begin{tabular}{lc}
\hline Organisms & No (\%) of patients \\
\hline Streptococci & $18(45)$ \\
Strep viridans & $11^{*}$ \\
Non-haemolytic streptococci & 6 \\
Group C streptococci & 1 \\
Staphylococci & $13(32 \cdot 5)$ \\
Staph aureus & 7 \\
Staph albus & 6 \\
Mixed growth & 1 \\
Haemophilus infuenzae and Strep & \\
viridans (latter predominant) & $9(22 \cdot 5)$ \\
No growth & 9 \\
\hline
\end{tabular}

*Includes the patient with mixed growth.

Table 4 Distribution of organisms in relation to the predisposing factors within each clinical class

\begin{tabular}{|c|c|c|c|c|}
\hline Predisposing factors & No of patients & Streptococci & Staphylococci & No growth \\
\hline $\begin{array}{l}\text { (a) Patients in NYH } \\
\text { Normal } \\
\text { Congenital } \\
\text { Rheumatic }\end{array}$ & $\begin{array}{l}\text { ctional class III } \\
4 \\
5 \\
4\end{array}$ & $\begin{array}{c}e^{11}(32 \cdot 5 \% \text { of } \\
2 \\
5 \\
1\end{array}$ & 2 & $\begin{array}{l}2 \\
1\end{array}$ \\
\hline Total & 13 & 8 & 2 & 3 \\
\hline $\begin{array}{l}\text { (b) Patients in NYH } \\
\text { Normal }^{*} \\
\text { Congenital } \\
\text { Rheumatic }\end{array}$ & $\begin{array}{l}\text { ctional class } I V \\
17 \\
5 \\
4\end{array}$ & $\begin{array}{c}e^{11}(65 \% \text { of al } \\
5 \\
3 \\
2\end{array}$ & $\begin{array}{l}7 \\
2 \\
1\end{array}$ & 1 \\
\hline Total & 26 & 10 & 10 & 6 \\
\hline
\end{tabular}

*One patient with a normal valve was in class II and the valve grew staphylococci. 


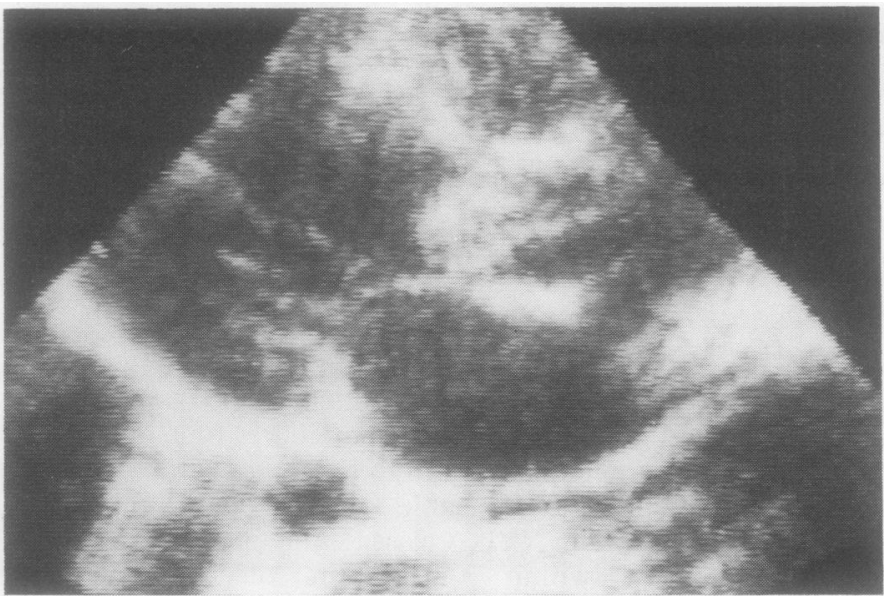

Fig 1 Two-dimensional echocardiogram showing extensive vegetations over the aortic valve.

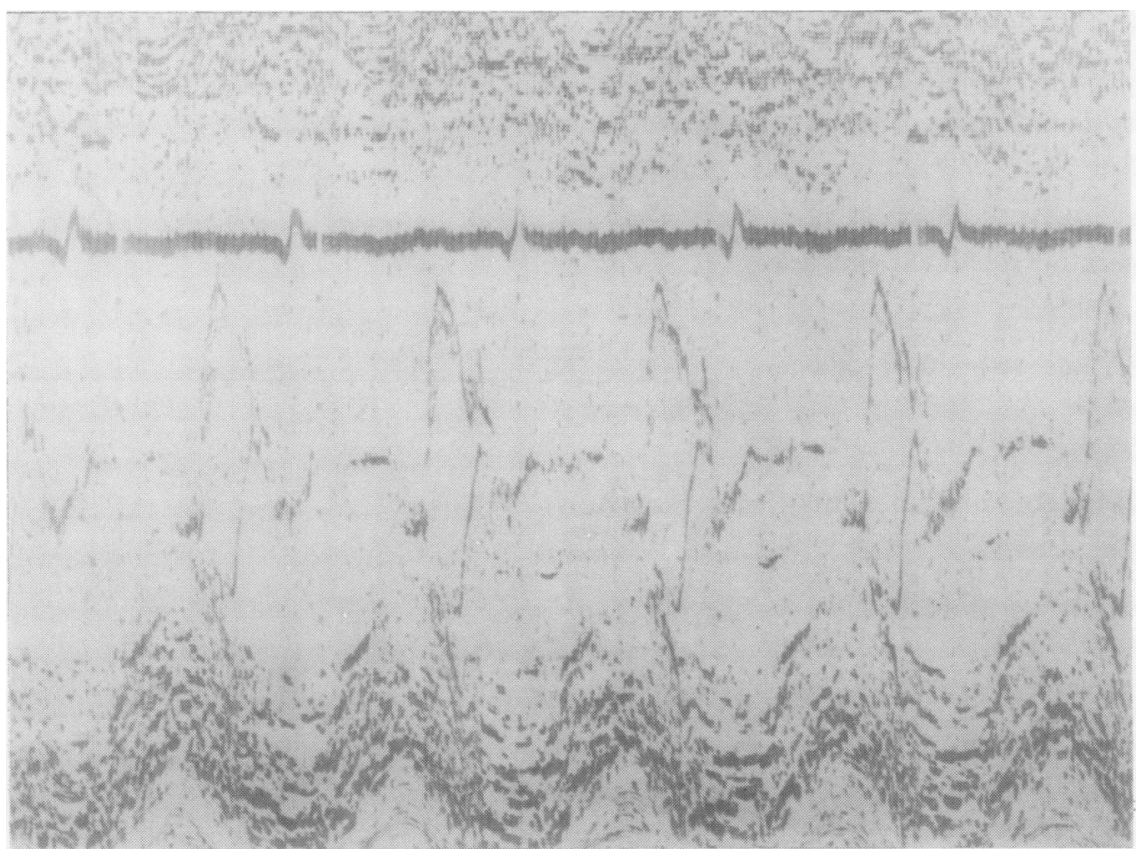

Fig 2 M-mode echocardiogram showing premature closure of the mitral valve in a patient with severe aortic regurgitation of recent origin.

tence syndrome and were in intractable heart failure from the start. The pulse pressure was small in each patient, and the sharp diastolic fall of severe aortic regurgitation was conspicuous by its absence.

In all patients antibiotics were started on the basis of clinical suspicion alone. In culture-positive patients the appropriate antibiotics were started as soon as the report was available. Most of the patients with negative blood cultures received a combination of either gentamicin and benzylpenicillin (with or without porobenecid) or gentamicin and flucloxacillin. Altogether 18 patients were operated on within two weeks from the start of their antibiotic treatment and in 12 patients the interval was less than four days. Appropriate postoperative treatment was always continued intravenously for at least four weeks.

\section{Results}

Aortic valve replacement was performed in 31 patients, mitral valve replacement in four, and replacement of both valves in five. .

In 22 out of 40 patients the affected valves were 
Table 5 Findings at operation

\begin{tabular}{ll}
\hline Pathological findings & No of patients \\
\hline Vegetations & All patients \\
Leafiet destruction & 21 \\
Torn aortic cusps & 16 \\
Left coronary cusp alone & 10 \\
Right coronary cusp alone & 2 \\
Non-coronary cusp alone & 0 \\
Both right and left cusps & 2 \\
All three cusps & 3 \\
Subannular abscess formation & 17 \\
Fistula formation & 1 \\
"Jet" lesion on mitral valve & 3 \\
Ruptured chordae tendinae & 4 \\
\hline
\end{tabular}

found to be otherwise normal and most of these patients were in NYHA class IV heart failure, in contrast to the patients with pre-existing rheumatic or congenital lesions of the valves (table 2).

Streptococci were the commonest organisms isolated from the preoperative blood cultures; in nine patients $(22.5 \%)$ the blood culture was negative (table 3 ). When the organisms were related to the NYHA functional class (table 4), there was a higher incidence of staphylococcal infection in the group with class IV heart failure (10 out of 26 ) than in the class III group (two out of 13).

Both M-mode echocardiography (in 23 patients) and in recent years two-dimensional echocardiography (in six patients) were used for preoperative assessment (fig 1). Out of 20 patients with severe aortic regurgitation, 14 showed premature closure of mitral valve in M-mode echocardiography (fig 2). All these patients were operated on within 72 hours of their investigations and all survived.

The findings are summarised in table 5. Vegetations were present on all valves, and the left coronary cusp was more commonly torn or detached than the right or non-coronary cusp among the incompetent aortic valves. At the time of operation active infection was present in 11 out of 40 patients and in eight patients organisms were grown from the excised valves. In 17 out of 36 excised aortic valves there was subannular abscess formation and in 12 of these patients there was preoperative evidence of an atrioventricular conduction defect. In six patients multiple abscess cavities were found to be interconnected under the annulus, with loss of circumferential supporting tissue. In these patients stitches were applied to the base of the mitral leaflet and the muscles of the left ventricular outflow tract, and in one case the right ventricular outflow tract was opened for secure placement of sutures. Insertion of a larger-sized prosthesis appeared to be easier in these patients. Size 27 aortic prostheses were inserted in 11 out of 17 patients with aortic root abscess and in five out of 19 patients with infected aortic valves but without any abscess around the root $(p<0.05)$.

There were eight postoperative deaths, giving an operative mortality rate of $20 \%$. Six out of 31 patients died after aortic valve replacement and two out of five after aortic and mitral valve replacement. Necropsy was carried out in six patients. A postoperative low output state was the commonest cause of death (four out of eight patients) and all these patients had sustained a single or repeated cardiac arrest before their operation; after resuscitation they remained critically ill until operation, for 18-52 hours (table 6). In contrast, two patients who had a cardiac arrest soon after the induction of anaesthesia had an immediate cardiopulmonary bypass established, and both survived the operation and remained well.

One patient died of acute aortic dissection (type 1 ) on the ninth postoperative day. Another patient, who had sustained multiple cerebral embolism before the operation, died of cerebral haemorrhage due to rupture of a mycotic aneurysm and two others died following postoperative cardiac arrest, one of whom was thought to have had pacemakerinduced ventricular fibrillation.

The mortality in patients with severe haemodynamic failure was significantly higher when surgery was delayed for more than four days. Out of 26 patients in functional class IV, 19 were operated on within four days of their haemodynamic deterioration and all survived. The operation, however, was

Table 6 Details of preoperative cardiac arrest and causes of death in the four patients with postoperative low ouput state

\begin{tabular}{|c|c|c|c|}
\hline Operation & No of cardiac arrests & $\begin{array}{l}\text { Interval }(h) \text { between cardiac } \\
\text { arrest and bypass }\end{array}$ & Cause of death \\
\hline AVR, MVR & 1 & 18 & $\begin{array}{l}\text { Postoperative low ouput } \\
\text { state; subendocardial infarction }\end{array}$ \\
\hline AVR & 3 & 52 & $\begin{array}{l}\text { Postoperative low output state; } \\
\text { died 3rd week, renal failure }\end{array}$ \\
\hline AVR & 4 & 27 & $\begin{array}{l}\text { Postoperative low output state; } \\
\text { acute pancreatitis }\end{array}$ \\
\hline AVR & 2 & 31 & $\begin{array}{l}\text { Postoperative low output state; } \\
\text { brain death, died } 2 \text { nd week }\end{array}$ \\
\hline
\end{tabular}

AVR-aortic valve replacement; MVR-mitral valve replacement. 
Table 7 Details of the four late deaths (all after aortic valve replacement)

\begin{tabular}{ll}
\hline Survival $(m)$ & Cause of death \\
\hline 42 & Chronic renal failure \\
53 & Cerebrovascular accident \\
24 & Clotted prosthesis (Björk) \\
14 & Chronic renal failure \\
\hline
\end{tabular}

Table 8 Preoperative antibiotic treatment and reinfection in the 16 survivors, followed up for at least three years, of 23 operations (1972-8)

\begin{tabular}{lll}
\hline $\begin{array}{l}\text { Duration of antibiotic } \\
\text { before operation }\end{array}$ & No of patients & Reinfection \\
\hline$<4$ days & 5 & \\
$<2$ weeks & 1 & 1 \\
$\geqslant 2$ weeks & 10 & \\
\hline
\end{tabular}

delayed in the remaining seven patients and none survived the operation ( $\mathrm{p}=0.000003)$.

There were four reoperations. One patient developed prosthetic endocarditis eight months after aortic valve replacement. In the second patient there was periprosthetic leakage without any evidence of infection. The leak was adjacent to an old abscess cavity. The third patient presented with a thrombosed mechanical prosthesis. In the fourth, who had both aortic and mitral valve replacement, the mitral heterograft calcified within two weeks and he required reoperation (details already published ${ }^{25}$ ). There were four late deaths, from one to four years after the native valve replacement (table 7). There was no evidence of infection at the time of death. Among the 16 surviving patients out of the 23 having native valve replacements up to 1978 , who were followed up for at least three years (mean 5.3 years), there was one episode of reinfection (table 8).

Currently there are 28 survivors, with a mean follow-up of four years (range six months to 10 years). Twelve of them were in NYHA class III and 16 were in class IV at the time of their native valve replacement. Now 24 patients are in NYHA functional class I and four in class II.

\section{Discussion}

Since the introduction of potent antibiotics, intractable heart failure has replaced sepsis as the commonest cause of death in bacterial endocarditis. ${ }^{12}$ Now, almost 20 years after the first successful valve replacement for bacterial endocarditis, ${ }^{13}$ it is apparent that a large proportion of patients with severe heart failure can be saved by rapid surgical interven- tion. Moreover, there is evidence that delay in surgery only increases the morbidity and mortality, ${ }^{13-15}$ and the apparent inadequacy of preoperative antibiotic treatment in patients requiring urgent operation does not necessarily increase the risk of reinfection. ${ }^{1617} \mathrm{~A}$ logical approach to further improvement in surgical management would be to identify the patients who are at high risk of developing severe heart failure and to pursue a policy of operating on patients at risk before rather than after they have developed irreversible pulmonary oedema and myocardial dysfunction.

In this study 22 patients $(55 \%)$ presented with infected valves which were anatomically and histologically normal. By contrast, a review of published cases in 1974 showed that only $28 \%$ of patients had presented with a normal valve. ${ }^{18}$ This appears to be a recent trend, and half of the patients in our series have presented only during the last three years. This has also been confirmed in a multicentre collaborative study. ${ }^{19}$ Recent studies also show an increasing incidence of staphylcoccal infection. ${ }^{814}$ Staphylococci tend to infect the normal valves more frequently than the valves with preexisting disease ${ }^{19}$ and usually cause rapid destruction of the valves resulting in severe haemodynamic failure. ${ }^{47}$ In our series 17 out of 22 patients with normal valves were in functional class IV heart failure, and most (12 out of 17) either were infected by staphylococci or had a negative preoperative blood culture.

The other subgroup of critically ill patients presented with the acute aortic incompetence syndrome. Classically, these patients do not have any appreciable aortic valve lesion and the normal left ventricle fails to cope with a sudden diastolic overload. As a result the left ventricular end-diastolic pressure rises sharply, causing premature closure of the mitral valve. ${ }^{20}$ Although the incidence of acute aortic incompetence syndrome due to endocarditis was insignificant, as reported in a review of published cases in $1974,{ }^{18}$ the potential danger in these patients was recognised as early as $1971 .^{21}$ In our series 13 patients presented with an acute aortic incompetence syndrome. At operation, 11 valves were found to be normal and two congenitally bicuspid and most (nine out of 13) were infected by staphylococci. Premature closure of mitral valve was diagnosed in 10 patients who were operated on urgently and were the only survivors of this subgroup.

The value of $\mathrm{M}$-mode echocardiography in native valve endocarditis and the clinical importance of diagnosing premature closure of mitral valve well before the development of irreversible pulmonary oedema has been well documented..$^{22} 23$ This study 
also confirms its value, particularly among the patients with moderate-to-severe aortic regurgitation of recent onset. Premature closure of mitral valve was diagnosed in 14 out of 20 such patients and all survived urgent operation.

Several recent reports have shown that the timing of surgical intervention in critically ill patients is the crucial factor for a successful outcome. ${ }^{1-10}$ None of our patients in NYHA class IV died if they were operated on within four days of their clinical deterioration (19 patients) but all died when the operation was delayed (seven patients). The difference is highly significant $(p=0.000003)$ and highlights the importance of urgent surgery. Prager $e t$ al, who reported no deaths after urgently performed aortic valve replacement in 14 consecutive patients, support our view. ${ }^{10}$

Cardiac arrest during medical treatment proved to be a significant risk factor in our patients unless it was followed by immediate operation. Mortality in patients who sustained cardiac arrest and remained critically ill for 18-52 hours was $100 \%$, whereas among the patients who had no such episode it was only $11 \%(p=0.0015)$. In two other patients immediate cardiopulmonary bypass was established after cardiac arrest and both survived.

Preoperative antibiotic treatment was apparently inadequate (lasting less than two weeks) in 18 of our patients and 11 of them had active infection at the time of valve replacement. In all survivors the postoperative antibiotic was continued intravenously for four to six weeks without any complications, and the incidence of reinfection was low (table 8 ) and bore no relation to the duration of preoperative antibiotic treatment. There has been no further occurrence of reinfection so far and our incidence is in fact similar to the reinfection rate $(4.4 \%)$ after valve replacement in patients without endocarditis. ${ }^{24} \mathrm{We}$ therefore agree with Jung et ${ }^{16}$ and believe that the duration of postoperative antibiotic treatment rather than any antibiotic regimen used before the operation is important for the prevention of reinfection.

This study indicates that patients with native valve endocarditis who have no pre-existing valvular lesions are more liable to develop severe haemodynamic failure than are patients with known valvular heart disease. M-mode echocardiography should be used to monitor premature closure of mitral valve in all patients with moderate-to-severe aortic regurgitation and premature closure should be considered as an important indication for urgent surgery. We have also confirmed that a delay of more than four days before operation in patients with haemodynamic failure is related to significantly higher mortality and cardiac arrest during medical management should be followed not only by resusci- tation but also by immediate cardiopulmonary bypass. Finally, the duration of preoperative antibiotic treatment does not have any influence on the incidence of reinfection and an acceptably low reinfection rate can be achieved by continuing appropriate postoperative antibiotics intravenously for at least four weeks.

We are grateful to Dr Robin Prescott, department of medical computing and statistics, University of Edinburgh, for his help in the analysis of the statistical data.

\section{References}

' Parrott JCW, Hill JD, Kerth WJ, Gerbode F. The surgical management of bacterial endocarditis: review. Ann Surg 1976;183:289-92.

${ }^{2}$ Wilcox BR, Murray GF, Starek PJK. The long term outlook for valve replacement in active endocarditis. $J$ Thorac Cardiovasc Surg 1977;76:860-3.

${ }^{3}$ Boyd AD, Spencer FC, Isom W, Cunningham JN, Reed GE, Acinapura AJ, Tice DA. Infective endocarditis: an analysis of 54 surgically treated patients. $J$ Thorac Cardiovasc Surg 1977;73:23-30.

${ }^{4}$ Richardson JV, Karp RB, Kirklin JW, Dismukes WE. Treatment of infective endocarditis: a 10 year comparative analysis. Circulation 1978;58:589-97.

${ }^{5}$ Wilson WR, Danielson GK, Ginliani ER, Washington JA, Jaumin PM, Geraci JE. Cardiac valve replacement in congestive heart failure due to infective endocarditis. Mayo Clin Proc 1979;54:223-6.

${ }^{6}$ Kinsley RH, Colsen PR, Bakst A. Emergency valve replacement for primary infective endocarditis. $S$ Afr Med J 1978;53:86-8.

${ }^{7}$ Lowes JA, Williams G, Tabaqchali S, et al. 10 years of infective endocarditis at St Bartholomew's Hospital: analysis of clinical features and treatment in relation to prognosis and mortality. Lancet 1980;i:133-6.

${ }^{8}$ English TAH, Ross JK. Surgical aspects of bacterial endocarditis. $\mathrm{Br}$ Med J 1972;iv:598-602.

9 Scott SM. Early operative intervention in aortic bacterial endocarditis. Ann Thorac Surg 1981;32:327-8.

${ }^{10}$ Prager RL, Maples MD, Hammon JW, Friesinger GC, Bender HW. Early operative intervention in aortic bacterial endocarditis. Ann Thorac Surg 1981;32: 347-50.

${ }^{11}$ Braunwald E. Heart disease. Vol. 1. Philadelphia: WB Saunders, 1980:501.

12 Lerner PI, Weinstein L. Infective endocarditis in the antibiotic era. $N$ Engl J Med 1966;274:199-206.

${ }^{13}$ Wallace AG, Young WG, Osterhout SO. Treatment of acute bacterial endocarditis by valve excision and replacement. Circulation 1965;31:450-3.

14 Lau JM, Guinn GA, Beall AC, Mattox KL, Young JB, De Bakey $M$. Operative techniques in infective endocarditis. Ann Thorac Surg 1981;32:351-6.

15 Buckley MJ, Mundth ED, Daggett WM, Austen WG. Surgical management of the complications of sepsis involving the aortic valve, aortic root and ascending aorta. Ann Thorac Surg 1971;12:391-9.

16 Jung JY, Saab SB, Almond CH. The case for early surgi- 
cal treatment of left sided primary infective endocarditis. J Thorac Cardiovasc Surg 1975;70:509-18.

${ }^{17}$ Wilson WR, Danielson GK, Giuhiani ER, Washington JA, Jaumin PM, Geraci JE. Valve replacement in patients with active infective endocarditis. Circulation 1978;58:585-8.

${ }^{18}$ Black S, O'Rourke RA, Karliner JS. Role of surgery in the treatment of primary infective endocarditis. Am J Med 1974;56:357-69.

${ }^{19}$ Kaplan EL, Rich H, Gersony W, Manning J. A collaborative study of infective endocarditis in the 1970s. Circulation 1979;59:327-35.

${ }^{20}$ Morganroth J, Perloff JK, Zeldis SM, Dunkman WB. Acute severe aortic regurgitation. Ann Intern Med 1977;87:223-32.

${ }^{21}$ Wise JR, Bental HH, Cleland WP, Goodwin JF, Hallidie
Smith KA, Oakley CM. Urgent aortic valve replacement for acute aortic regurgitation due to infective endocarditis. Lancet 1981;ii:115-21.

${ }^{22}$ Mann T, MacLaurin L, Grossman W, Craigs E. Assessing the haemodynamic severity of acute aortic regurgitation due to infective endocarditis. $N$ Engl J Med 1975;293:108-13.

${ }^{23}$ Roy P, Tajik A, Giuliani ER, Schattenberg TT, Gau GT, Frye RL. Spectrum of echocardiographic findings in bacterial endocarditis. Circulation 1976;53:474-82.

${ }^{24}$ Quenzer RW, Edwards LD, Levin S. A comparative study of 48 host valve and 24 prosthetic valve endocarditis. Am Heart J 1976;92:15-22.

${ }^{25}$ Forfar JC, Cotter L, Morritt GN. Severe and early stenosis of porcine heterograft mitral valve. Br Heart J 1978;40:1184-7. 